\title{
Predation of Otaria flavescens over artisanal fisheries in Uruguay: OPPORTUNISM OR PREY SELECTIVITY?
}

\author{
DiANA SZTEREN ${ }^{1}$
}

\begin{abstract}
Interactions between pinnipeds and fisheries have become an increasingly important topic for fisheries and pinniped management. In particular, the predatory behavior on fisheries is a cause of concern in many places because seals frequently opt to take fish from fishers' gear rather than searching and caching their own food. Sea lion prey selectivity on artisanal fisheries catches was analyzed, with the aim of determining if the predatory behavior was opportunistic or selective. Data were collected through direct observations of sea lion predation onboard during routine fishing trips at four fishing ports on the Uruguayan coast (Buceo, Piriápolis, La Paloma and Cabo Polonio), during two time periods (winter and spring-summer) in 1997/1998. The proportion of the most consumed fish and those most caught by the fishery was analyzed. An odds ratio was calculated as a selection index, using the number of prey items consumed by sea lions, and those caught by the fishery. Two general predatory strategies are apparent, one at the two fishing ports located on La Plata River estuary (Buceo and Piriápolis) and the second at the other two localities on the Atlantic Ocean coast. In the first strategy, the most consumed prey were the same most caught by the fishery (Macrodon ancylodon and Urophycis brasiliensis), suggesting an opportunistic behavior. However, at La Paloma and Cabo Polonio sea lions preyed mostly upon species which were not the main for the fishery (Cynoscion guatucupa in La Paloma, and Mustelus schmitti in Cabo Polonio) and exhibited selections and rejections of other species. Preferences and rejections however, represented small proportions of sea lion consumption and of the fishery catch. Seasonal differences in prey consumption and catches, as well as in selections and rejections were also evident. In some cases prey selections were reversed between both time periods. There was no evidence of an important conflict between sea lions and artisanal fisheries because the most selected species were not the most important for the fishery.
\end{abstract}

Resumen: Las interacciones entre Pinnípedos y pesquerías representan un tema cada vez mas importante en el manejo de Pinnipedos y de pesquerías. Particularmente, la depredación sobre las capturas pesqueras es de interés, ya que en muchos sitios los lobos marinos optan por alimentarse de peces capturados en los artes de pesca facilitando así, la búsqueda y captura de alimento. Con el objeto de determinar si el comportamiento de depredación del lobo marino de un pelo es oportunista o selectivo, se analizó la selectividad de presas sobre las capturas de la pesca artesanal. La predación de lobos marinos fue observada directamente a bordo durante salidas rutinarias de pesca en 4 localidades de la costa Uruguaya (Buceo, Piriápolis, La Paloma y Cabo Polonio), durante dos períodos de tiempo (invierno y primavera-verano) en 1997/1998. Se calculó el índice de selectividad usando el número de individuos consumidos por los lobos marinos y capturados por la pesca artesanal. Aparentemente existirían dos estrategias de depredación: una en los puertos ubicados en el estuario del Río de la Plata (Buceo y Piriápolis) y la segunda en las otras dos localidades en la costa del Océano Atlántico. En la primera, los peces más consumidos por los lobos marinos fueron también los más capturados por la pesquería (Macrodon ancylodon y Urophycis brasiliensis respectivamente), lo que sugiere un comportamiento oportunista. En La Paloma y Cabo Polonio, los lobos marinos depredaron mayormente sobre especies que no eran las más importantes para la pesquería (Cynoscion guatucupa en La Paloma y Mustelus schmitti en Cabo Polonio) y exhibieron selecciones y rechazos de otras especies. Sin embargo, estas preferencias y rechazos representaron bajas proporciones del consumo de los lobos marinos y de las capturas pesqueras. También se evidenciaron diferencias estacionales en las proporciones consumidas y capturadas, así como en las especies preferidas y rechazadas. En algunos casos hubo una inversión de los items preferidos entre los períodos comparados. No se encuentran evidencias de que el conflicto con la pesca artesanal sea importante, ya que los lobos marinos no seleccionan preferentemente las especies más importantes para la pesca artesanal.

Keywords: Otaria flavescens, prey selectivity, opportunism, artisanal fishery, Uruguay.

\section{Introduction}

The South American sea lion (Otaria flavescens) is distributed from southern Brazil to southern Argentina along the Atlantic Ocean, and around the Chilean and Peruvian coasts along the Pacific Ocean (Vaz Ferreira, 1975). The population of South American sea lions in Uruguay is represented by approximately 12,000 animals, declining at a rate of about $2 \%$ yearly (Páez, 2005²). The causes of this decline are yet unknown, but feeding problems related with their interaction with fisheries, including illegal mortality by fishers, are the main suspected causes.

Interactions between pinnipeds and fisheries have become an increasingly important topic for fisheries and pinniped management, and many studies have been directed to this topic worldwide. Ecological interactions, represented by the depletion of important prey species by fishing activities, can have adverse effects on marine mammal populations. These have been mentioned as a potential cause of population decrease of several pinniped species (e.g. Ainley et al., 1982, Merrick et al., 1987, 1997; and citations in Werner and Campagna, 1995). Also, the predatory behavior

\footnotetext{
${ }^{1}$ Sección Zoología Vertebrados. Facultad de Ciencias. Iguá 4225. Montevideo, 11400, Uruguay. E-mails: diana@fcien.edu.uy, dszteren2002@yahoo.com.

2 Páez, E. (2005) ¿ Yo...? Otaria ¿Y usted...? Terceras Jornadas de Conservación y Uso Sustentable de la Fauna Marina. 14 a 17 de setiembre de 2005. Montevideo, Uruguay.
} 
on fisheries is a cause of concern and controversy because of the real or perceived cost to fisheries, causing a threat to fish stocks and fishing gear (Marsh et al., 2003). Seals have learned to follow fishing boats and take advantage of the caught fish (Bonner, 1982; David and Wickens, 2003). In this sense, seals have been termed "lazy opportunistic feeders" (Johnson and Karamanlidis, $2000^{3}$ ) as they frequently opt to take fish from fishers' gear rather than hunt on their own (Moore, 2003).

In the perspective of foraging theory, the selection of an optimal diet by an animal assumes the adoption of some type of "optimal feeding". Selective predation occurs when the relative frequencies of prey items in a predator' diet differ from the relative frequencies of those items in the environment. On the other hand, an opportunistic predator takes prey in the same proportion as available in the environment, consuming mostly what is more available at each moment or place. It implies changing between prey species and/or areas according to prey availability (Kajimura, 1984). At low levels of prey abundance, opportunistic feeders may abandon a food source and turn to a more abundant species (Beverton, 1985). Concerning the width of the trophic spectrum, an animal is a generalist when it preys upon a large range of food types, shows a large collection of feeding behaviors, or in measurable terms, on the basis of relative ability in extracting energy from food (Schoener, 1972). On the contrary, a specialist predator exploits few resources or the diet is dominated by a specific range of prey types (or lengths).

Many authors have emphasized the need for behavioral information before key questions can be answered about marine mammal - fisheries interaction (e.g. Beverton, 1985). For O. flavescens, the few studies analyzing sea lion prey selectivity reflect contrasting results. Koen Alonso et al. (2000) in southern Argentina described an opportunistic behavior at industrial fisheries, while George-Nacimento et al. (1985) reported preference towards the non commercial hake Macruronus magellanicus in relation to bottom trawls in central Chile. These studies, as well as others related with prey selection by a pinniped, have been based in the fishery landings as a proxy of the environmental availability, and prey species identified from hard remains in stomach contents or scats.

For Uruguayan waters, data on sea lion prey distribution and abundance are scarce. Some preliminary information on the diet of this species has been reported by Naya et al. (2000). Concerning interactions with fisheries, South American sea lions interact mainly with coastal fisheries, frequently following fishing boats and preying upon entangled fish.
As a consequence of these conflicts, sea lions are currently associated with artisanal fishermen low catches. Artisanal fisheries on the coast usually employ set gillnets or bottom longlines, and rely on manual labor from small boats (less than $9 \mathrm{~m}$ long). Gillnets are between 50 and $80 \mathrm{~m}$ long and between 2 and $4 \mathrm{~m}$ high and are set on the bottom in groups of 3 to 5 attached nets. Longlines are also bottom set and each one consists in 100 baited hooks. Only one study quantified the damage caused by sea lion predation to artisanal fishing activity at the Uruguayan coast (Szteren and Páez, 2002), the authors reporting that sea lions were not the main responsible for low catches. Despite the paucity of information available to help understand the complexity of this interaction, the knowledge of pinniped diet and its interaction with fisheries is a valuable tool in order to understand and manage their populations.

In this paper, I analyzed South American sea lion prey consumption on artisanal fishing catches observed during this activity, with the objective of evaluating diet selectivity of sea lions preying on fish caught by artisanal fisheries. The aim of this study was to determine whether sea lions exhibit an opportunistic behavior or prey selectively towards any fish species, and to compare four different fishing ports and two seasons. Despite the abundant literature on diet composition, few studies address feeding aspects associated to seasonality, prey availability and prey preference. This is very important in assessing the role of South American sea lions as predators in association with fisheries, and this work represents a complementary view to the problem of interactions and competition with artisanal fishery.

\section{Methodology}

From July 1997 to February 199848 fishing trips were monitored in four locations along the Uruguayan coast, from west to east: Buceo, Piriápolis (both on La Plata River estuary), La Paloma and Cabo Polonio on the Atlantic coast (Figure 1). These included 12 trips at each port during routine fishing activities and a total of 53 fishing events recorded (Szteren, 1999; Szteren and Páez, 2002). The time period was divided into two seasons: winter (July to September) and spring-summer (October to February)

At Piriápolis and La Paloma two fishing gear were used, bottom gillnets and longlines, while at Buceo and Cabo Polonio only gillnets were used. Gillnets were usually set and retrieved during the same trip, leaving 2-5 hours of "active fishing time". Longlines were typically set at sunset and retrieved the next morning. At Buceo fishermen usually used a mean of 8 gillnets,

\footnotetext{
${ }^{3}$ Johnson, W.M. and Karamanlidis, A.A. (2000) When fishermen save seals. The Monachus Guardian 3: 1-8. http://www.monachus.org/ mguard05/05covsto.htm.
} 
at Piriápolis 4-5, at La Paloma 15 and at Cabo Polonio 22. The mean number of longlines used in Piriápolis was 13-14 and at La Paloma 30. The mesh size used in general was $8 \mathrm{~cm}$ at Buceo, and 10, 11 and $14 \mathrm{~cm}$ knot to knot in the other ports.

Fish catches were directly observed onboard during the fishing activity, when the number of individuals of each species was determined and counted as soon as they were fished. Also, the number of fish species consumed by sea lions at the surface was recorded, as well as the damaged fish onboard (i.e.

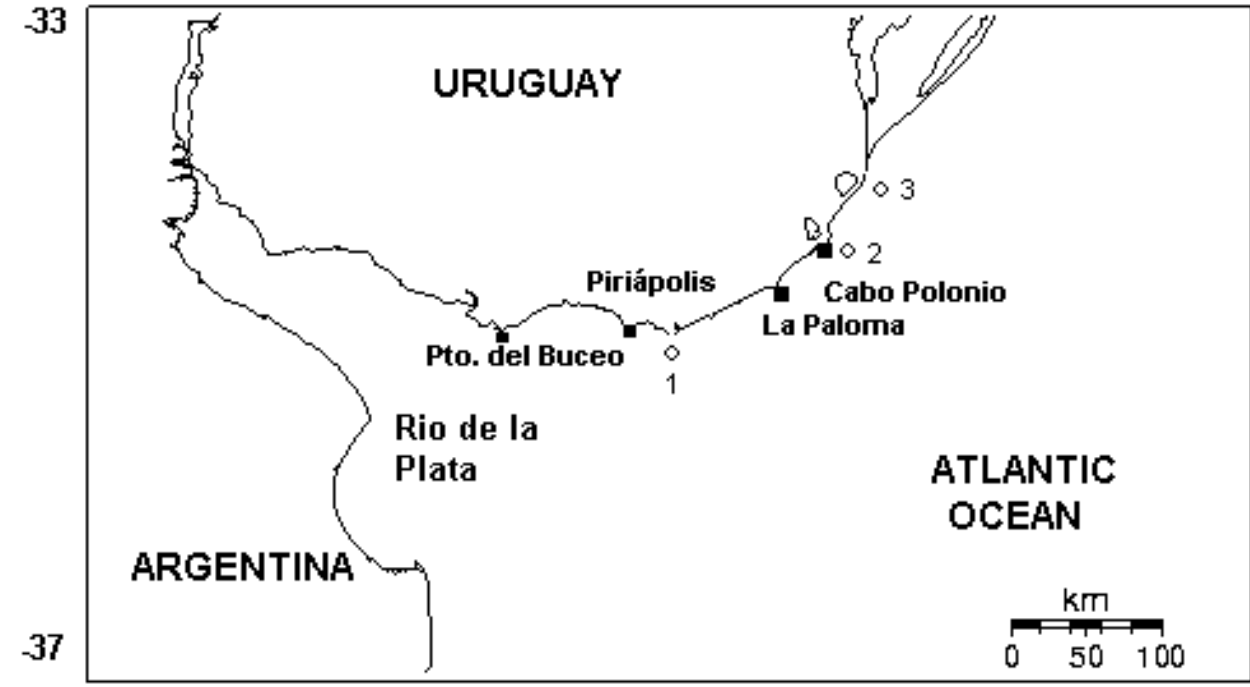

Figure 1. Location of the fishing ports sampled: Buceo, Piriapolis, La Paloma and Cabo Polonio (in black squares). Sea lion rookeries are shown in white circles. 1. Lobos island, 2. Castillo Grande and Torres islands and 3. La Coronilla islands.

fish with bites, or fish

remains). In order to estimate the weight of the lost fish and the total catch, a subsample of caught fish of each species was weighted individually, then I calculated the weight distribution function and expanded it to the number of caught or lost fish (Szteren, 1999).

Estimation of prey selection on fishery catches was performed by the calculation of the odds ratio $(O R)$ (Agresti, 1984; Tollit et al., 1997) as a selection index. This was calculated for each fishing port, separately for each fishing gear, and then for each season at each port. The odds ratio is given by:

$O R=\frac{p 1 . q 2}{p 2 . q 1}$

where, $p 1$ is the proportion of the diet consisting of a given prey item, $p 2$ is the relative abundance of that species in fishing gear catches, $q 1$ is the proportion of the diet contributed by all the other prey items and $q 2$ is the relative abundance as a proportion of all other prey items in the fishing gear catches. In this case, I used sea lion consumption observed during fishing activities as the diet, and the fisheries catches as the available offer for sea lions.

Then, logarithms of odds ratios were calculated, so that positive values indicated prey that were positively selected by seals, and negative values reflect prey ignored by seals (Tollit et al., 1997). As those authors pointed out, when using biomass estimates species with low relative abundance at sea or in the diet were very sensitive to potential errors in the calculation of odds ratios. As recommended by Tollit et al. (1997), only those species with an odds ratio $\geq 1$ for selected items and $\leq-1$ for rejected items were analyzed. The standard deviation of $\log O R$ was estimated as:

$$
S E(O R)=\sqrt{\frac{1}{n 1}+\frac{1}{n 2}+\frac{1}{q 1}+\frac{1}{q 2}}
$$

The confidence intervals are given by:

$$
\log (O R) \pm\left[\frac{Z p}{2} * S E(O R)\right]
$$

Finally, the width of the trophic spectrum was estimated for sea lions and fishery at each location, to determine whether the diet and catcheswere specialist or generalist. For that I used the Levin's index (Krebs, 1999), calculated as:

$$
B_{j}=\frac{1}{\sum p_{j}^{2}}
$$

where, $B j$ is the niche width $p^{2}$ is the proportion of item $\mathrm{j}$ in the diet Values $<3$ indicate a specialist diet, while values $>3$ represent a generalist diet.

\section{Results}

\section{Local preferences}

Sea lions consumed fish species in different proportions according to the fishing locality. Fish were usually not discarded, unless it was too small or without commercial use (e.g. Conger japonicus at Piriápolis). Fisheries also caught diverse species in different localities, from which only two or three species reached $80 \%$ of the catch. The most consumed prey at Buceo was the same most caught by the fishery (king weakfish, Macrodon ancylodon) (Table 1). According to the selectivity index, no fish was positively or negatively selected (Table 2). At Piriápolis, both the 
longline fishery and the sea lions mainly caught Urophycis brasiliensis (Brazilian codling) (Table1). In this fishing port, sea lions did not prey preferentially over any fish species (Table 3). Gillnets are seldom used in Piriápolis, and in this particular case, only one fishing event was recorded and was unsuccessful (zero catch) and sea lions only consumed U. brasiliensis (Table1). No species was selected or rejected (Table 3).

Table 1. Proportion of fish species caught in fisheries (P fshy) and consumed by sea lions (P sl) at each fishing port. Only proportions $>0.04$ in at least one of the components are shown.

\begin{tabular}{|c|c|c|c|c|c|c|}
\hline \multirow[b]{2}{*}{ LOCALITY } & \multicolumn{3}{|c|}{ GILLNETS } & \multicolumn{3}{|c|}{ LONGLINES } \\
\hline & & P fshy & P sl & & P fshy & P sl \\
\hline \multirow[t]{5}{*}{ Buceo } & Macrodon ancylodon & 0.76 & 0.64 & & & \\
\hline & Menticirrhus americanus & 0.02 & 0.09 & & & \\
\hline & Micropogonias furnieri & 0.13 & 0.04 & & & \\
\hline & Brevoortia sp. & 0.08 & 0.23 & & & \\
\hline & $\mathrm{N}=6$ & $\mathrm{~W}=95.4 \mathrm{Kg}$ & $\mathrm{W}=5.8 \mathrm{Kg}$ & & & \\
\hline \multirow[t]{6}{*}{ Piriápolis } & Urophycis brasiliensis & 0 & 1 & U. brasiliensis & 0.67 & 0.68 \\
\hline & & & & C. guatucupa & 0.12 & 0.26 \\
\hline & & & & C. japonicus & 0.11 & 0 \\
\hline & & & & M. furnieri & 0.05 & 0 \\
\hline & & & & Brevoortia sp. & 0.01 & 0.06 \\
\hline & $\mathrm{N}=1$ & $\mathrm{~W}=0 \mathrm{Kg}$ & $\mathrm{W}=2.9 \mathrm{Kg}$ & $\mathrm{N}=8$ & $\mathrm{~W}=468.3 \mathrm{~K}$ & $\mathrm{~W}=50.9 \mathrm{Kg}$ \\
\hline \multirow{5}{*}{$\begin{array}{l}\text { La } \\
\text { Paloma }\end{array}$} & Mustelus schmitti & 0.91 & 0.20 & C. guatucupa & 0.34 & 0.88 \\
\hline & Urophycis brasiliensis & 0.05 & 0 & U. brasiliensis & 0.37 & 0.12 \\
\hline & Cynoscion guatucupa & 0.01 & 0.63 & M. schmitti & 0.29 & 0 \\
\hline & Parona signata & 0 & 0.17 & \multirow{2}{*}{$\mathrm{N}=3$} & \multirow{2}{*}{\multicolumn{2}{|c|}{$\mathrm{W}=1310.8 \mathrm{Kg} \quad \mathrm{W}=22.6 \mathrm{Kg}$}} \\
\hline & $\mathrm{N}=3$ & $\mathrm{~W}=980.9 \mathrm{Kg}$ & $\mathrm{W}=11.3 \mathrm{Kg}$ & & & \\
\hline \multirow{5}{*}{$\begin{array}{l}\text { Cabo } \\
\text { Polonio }\end{array}$} & Mustelus schmitti & 0.81 & 0.24 & & & \\
\hline & Cynoscion guatucupa & 0.11 & 0.26 & & & \\
\hline & Squatina argentina & 0.04 & 0.38 & & & \\
\hline & Urophycis brasiliensis & 0.02 & 0.09 & & & \\
\hline & $\mathrm{N}=10$ & $\mathrm{~W}=701.6 \mathrm{Kg}$ & $\mathrm{W}=33.5 \mathrm{Kg}$ & & & \\
\hline
\end{tabular}

$\mathrm{N}=$ number of fishing trips considered, $\mathrm{W}=$ total weight

Table 2. Results of the odds ratio selectivity index (OR), logarithm of odds ratio (log OR), and its standard error (SE) for total data for each fish species and for each season at Puerto del Buceo.

\begin{tabular}{lcccccc}
\hline \hline FISH SPECIES & \multicolumn{2}{c}{ TOTAL } & \multicolumn{3}{c}{ BY SEASON } \\
\hline \hline & OR & $\begin{array}{c}\text { Log OR } \\
\text { (conf.limits) }\end{array}$ & SE & OR & Log OR & SE \\
Menticirrhus americanus & 4.03 & $\begin{array}{c}0.61 \\
(-2.53-3.74)\end{array}$ & 1.60 & W,SS: 0 & -- & - \\
Macrodon ancylodon & 0.54 & -0.27 & 0.89 & W: 3.51 & 0.54 & 1.54 \\
& & $(-2.02-1.49)$ & & SS: 0.13 & -0.87 & 1.74 \\
Brevoortia sp. & \multirow{2}{*}{3.31} & 0.52 & 1.04 & W: 15.61 & 1.19 & 1.77 \\
& & $(-1.52-2.57)$ & & SS: 17.30 & 1.24 & 1.55 \\
Micropogonias furnieri & 0.28 & -0.55 & 2.15 & SS: 0.54 & -0.27 & 2.24 \\
& & $(-4.76-3.66)$ & & & & \\
\hline \hline
\end{tabular}

OR of zero mean that the species was captured by fisheries but not consumed by sea lions. W: winter; SS: spring and summer. All fishing trips with gillnets. 
Table 3. Results of the odds ratio selectivity index (OR), logarithm of odds ratio, and its standard deviation for total data for each fish species and for each season at Piriápolis.

\begin{tabular}{lcccccc}
\hline \hline FISH SPECIES & & TOTAL & & \multicolumn{3}{c}{ BY SEASON } \\
\hline \hline & OR & $\begin{array}{c}\text { log OR } \\
\text { (conf. limits) }\end{array}$ & SE & OR & log OR & SE \\
Macrodon ancylodon & L,G: 0 & G, L: -- & & W, SS: 0 & -- & -- \\
Brevoortia sp. & L: 28.73 & L: 0.92 & 0.81 & W: 12.72 & 1.11 & 0.84 \\
& & $(-0.68-2.51)$ & & & $(-0.54-2.75)$ & \\
& & & & SS: 0 & -- & -- \\
Micropogonias furnieri & L: 0 & L: -- & -- & W,SS: 0 & -- & -- \\
Urophycis brasiliensis & L: 1.99 & L: 0.02 & 0.32 & W: 0.65 & -0.19 & 0.68 \\
& G: 0 & $(-0.61-0.64)$ & & & $(-0.52-1.14)$ & \\
& & G: * & & SS: 1.67 & 0.224 & 0.43 \\
Cynoscion guatucupa & L: 0.16 & L: 0.41 & 0.35 & W: 1.97 & 0.29 & 0.52 \\
& & $(-0.27-1.10)$ & & & $(-0.73-1.31)$ & \\
& & & & SS: 12.21 & 1.09 & 0.56 \\
Conger japonicus & L: 0 & L: -- & -- & W,SS: 0 & $(-0.02-2.19)$ & -- \\
\hline \hline
\end{tabular}

OR of zero mean than the species was captured by the fisheries but not consumed by sea lions, except when indicated by * or \& ( ${ }^{*}$ single species consumed, \& species consumed by sea lions, but not caught by fishery). W: winter; SS: spring and summer. G: fishing trips with gillnets, L: fishing trips with longlines

At La Paloma, fisheries using longlines concentrated on U. brasiliensis, C. guatucupa and Mustelus schmitti (narrownose smothound) in similar proportions, while sea lions consumed mostly Cynoscion guatucupa (Table 1). This species was positively selected (log $\mathrm{OR}=1.17$, Table 4). With gillnets, sea lions consumed C. guatucupa and M. schmitti in a lower proportion, and the fishery was directed basically to M. schmitti (Table 1). The selectivity index showed that sea lions also selected C. guatucupa $(\log \mathrm{OR}=2.39)$ and rejected M. schmitti $(\log \mathrm{OR}=-1.58$, Table 4$)$, as the former species was preyed upon in a greater proportion $(63 \%)$ than caught by the fishery $(1 \%)$. Finally, at Cabo Polonio, sea lions consumed mainly three species: Squatina argentina (Argentine angel shark), C. guatucupa, and $M$. schmitti, while the main target species for the fishery was M. schmitti (Table 1). In that fishing port, S. argentina was the preferred prey item, as it was preyed upon in a higher proportion than fished $(\log \mathrm{OR}=1.22$, Table 5). Likewise, $M$. schmitti was "avoided" by sea lions $(\log \mathrm{OR}=-1.11$, Table 5), as it represented $81 \%$ of the fisheries catches, but only $24 \%$ of the sea lion consumption (Table 1 ).

\section{Seasonal preferences}

At Buceo, the fishery caught $M$. ancylodon in high proportions both in winter and spring-summer seasons, and sea lions consumed that species mainly during winter. In summer the preferred prey of sea lions was Brevoortia sp. (menhaden) (Table 6). At
Piriápolis, the fishery caught mostly $U$. brasiliensis in winter. Sea lions concentrated on $U$. brasiliensis, and to a smaller extent also consumed C. guatucupa in both seasons. In spring-summer, $U$. brasiliensis was also the most caught and the most preyed by sea lions (Table 6). At La Paloma in winter the fishery caught mostly M. schmitti, and C. guatucupa in lower proportions, while sea lions preyed mostly upon the latter. In spring-summer the fishery concentrated on M. schmitti and $U$. brasiliensis and sea lions consumed C. guatucupa (Table 6). Finally, at Cabo Polonio the fishery as well as sea lions caught M. schmitti in higher proportions in winter. However, in spring-summer, this was also the main species for the fishery, but sea lions consumed mostly S. argentina and C. guatucupa in a smaller proportion (Table 6).

Preferences differed between seasons and in many cases the preferred or rejected prey in winter differed from that during spring-summer. For example, at Piriápolis Brevoortia sp. was positively selected in winter $(\log \mathrm{OR}=1.11$, Table 3$)$, while in spring-summer sea lions preferred C. guatucupa $(\log \mathrm{OR}=1.09$, Table 3). Also at Cabo Polonio the selected items differed (Umbrina canosai in winter and S. argentina in springsummer) $(\log \mathrm{OR}=1.67$ and 1.03, Table 5). Some fish species were preferred in both seasons, such as Brevoortia sp. in Buceo $(\log \mathrm{OR}=1.19$ in winter and 1.24 in spring-summer, Table 2) and C. guatucupa at La Paloma $(\log \mathrm{OR}=1.43$ in winter and 1.26 in springsummer, Table 4). 
Table 4. Results of the odds ratio selectivity index (OR), logarithm of odds ratio, and its standard deviation for total data for each fish species and for each season at La Paloma.

\begin{tabular}{|c|c|c|c|c|c|c|}
\hline \multirow[t]{2}{*}{ FISH SPECIES } & \multicolumn{3}{|c|}{ TOTALS } & \multicolumn{3}{|c|}{ BY SEASON } \\
\hline & OR & $\begin{array}{c}\log \text { OR } \\
\text { (conf. limits) }\end{array}$ & SE & OR & $\begin{array}{c}\log \text { OR } \\
\text { (conf. limits) }\end{array}$ & SE \\
\hline Micropogonias furnieri & G, L: 0 & G, L: -- & 0 & W, SS: 0 & & \\
\hline Urophycis brasiliensis & $\begin{array}{c}\text { G: } 0 \\
\text { L: } 0.23\end{array}$ & $\begin{array}{c}\text { G:-- } \\
\text { L: }-0.64 \\
(-1.92-0.65)\end{array}$ & L: 0.66 & $\begin{array}{c}\text { W: } 0 \\
\text { SS: } 0.35\end{array}$ & $\begin{array}{c}-0.45 \\
(-1.57-0.66)\end{array}$ & 0.57 \\
\hline Cynoscion guatucupa & $\begin{array}{l}\text { G: } 243.3 \\
\text { L: } 14.73\end{array}$ & $\begin{array}{c}\text { G: } 2.39 \\
(0.96-3.81) \\
\text { L: } 1.17 \\
(-0.12-2.45)\end{array}$ & $\begin{array}{l}\text { G: } 0.73 \\
\text { L: } 0.66\end{array}$ & $\begin{array}{l}\text { W: } 26.77 \\
\text { SS: } 18.06\end{array}$ & $\begin{array}{c}1.43 \\
(-0.39-3.24) \\
1.26 \\
(0.25-2.26)\end{array}$ & 0.93 \\
\hline Mustelus schmitti & $\begin{array}{l}\text { G: } 0.03 \\
\text { L: } 0\end{array}$ & $\begin{array}{c}\text { G: }-1.58 \\
(-3.04-(-0.12) \\
\text { L: -- }\end{array}$ & $\begin{array}{l}\text { G: } 0.75 \\
\text { L: } 0\end{array}$ & $\begin{array}{l}\text { W: } 0.05 \\
\text { SS: } 0\end{array}$ & $\begin{array}{c}-1.27 \\
(-3.08-0.55) \\
--\end{array}$ & 0.93 \\
\hline Parona signata & G: 0 & G: $\max$ & -- & W: 0,SS: \& & -- & -- \\
\hline
\end{tabular}

OR of zero mean that the species was captured by fisheries but not consumed by sea lions. W: winter; SS: spring and summer. G: fishing trips with gillnets, L: fishing trips with longlines

Table 5. Results of the odds ratio selectivity index (OR), logarithm of odds ratio, and its standard deviation for total data for each fish species and for each season at Cabo Polonio.

\begin{tabular}{|c|c|c|c|c|c|c|}
\hline \multirow[t]{2}{*}{ FISH SPECIES } & \multicolumn{3}{|c|}{ TOTALS } & \multicolumn{3}{|c|}{ BYSEASONS } \\
\hline & OR & $\begin{array}{c}\log \mathrm{OR} \\
\text { (conf. limits) }\end{array}$ & SE & OR & $\begin{array}{c}\log \mathrm{OR} \\
\text { (conf. limits) }\end{array}$ & SE \\
\hline Brevoortia sp. & 0 & -- & -- & W: 0 & -- & -- \\
\hline Urophycis brasiliensis & 4.66 & $\begin{array}{c}0.67 \\
(-0.58-1.92)\end{array}$ & 0.64 & $\begin{array}{c}\text { W: } 0 \\
\text { SS: } 2.25\end{array}$ & $\begin{array}{c}-- \\
0.35 \\
(-0.94-1.64)\end{array}$ & $\begin{array}{c}-- \\
0.66\end{array}$ \\
\hline \multirow[t]{2}{*}{ Cynoscion guatucupa } & 2.75 & $\begin{array}{c}0.44 \\
(-0.37-1.25)\end{array}$ & 0.41 & W: 2.19 & $\begin{array}{c}0.34 \\
(-1.26-1.94)\end{array}$ & 0.81 \\
\hline & & & & SS: 1.70 & $\begin{array}{c}0.23 \\
(-0.68-1.14)\end{array}$ & 0.47 \\
\hline \multirow[t]{2}{*}{ Mustelus schmitti } & 0.08 & $\begin{array}{c}-1.11 \\
(-1.92--0.30)\end{array}$ & 0.41 & W: 0.34 & $\begin{array}{c}-0.47 \\
(-1.83-0.88)\end{array}$ & 0.69 \\
\hline & & & & SS: 0.03 & $\begin{array}{c}-1.49 \\
(-3.06-0.08)\end{array}$ & 0.80 \\
\hline Parona signata & 0 & -- & -- & $\mathrm{W}: 0$ & -- & -- \\
\hline Squatina argentina & 16.44 & $\begin{array}{c}1.22 \\
(0.41-2.02)\end{array}$ & 0.41 & SS: 10.78 & $\begin{array}{c}1.03 \\
(0.19-1.88)\end{array}$ & 0.43 \\
\hline Merluccius hubbsi & 0 & -- & -- & W: 0 & -- & -- \\
\hline \multirow[t]{2}{*}{ Umbrina canosai } & 3.14 & $\begin{array}{c}0.50 \\
(-2.33-3.32)\end{array}$ & 1.44 & W: 46.38 & $\begin{array}{c}1.67 \\
(-1.02-4.36)\end{array}$ & 1.37 \\
\hline & & & & SS: 0 & -- & -- \\
\hline
\end{tabular}

OR of zero mean that the species was captured by fisheries but not consumed by sea lions. W: winter; SS: spring and summer. All fishing trips with gillnets. 
Table 6. Proportion of fish species caught in fisheries (P fshy) and consumed by sea lions ( $\mathrm{P}$ sl) at each fishing port and each season.

\begin{tabular}{|c|c|c|c|c|c|c|}
\hline \multirow[t]{2}{*}{ LOCALITY } & \multicolumn{3}{|c|}{ WINTER } & \multicolumn{3}{|c|}{ SUMMER-SPRING } \\
\hline & & P fshy & P sl & & P fshy & P sl \\
\hline \multirow[t]{6}{*}{ Buceo } & M. ancylodon & 0.58 & 0.83 & M. ancylodon & 0.67 & 0.21 \\
\hline & M. americanus & 0.33 & 0 & M. furnieri & 0.19 & 0.11 \\
\hline & Brevoortia sp. & 0.01 & 0.17 & Brevoortia sp. & 0.11 & 0.67 \\
\hline & C. guatucupa & 0.04 & 0 & & & \\
\hline & P. signata & 0.04 & 0 & & & \\
\hline & & $\mathrm{W}=97.5 \mathrm{Kg}$ & $\mathrm{W}=3.1 \mathrm{Kg}$ & & $\mathrm{W}=63.8 \mathrm{Kg}$ & $\mathrm{W}=2.0 \mathrm{Kg}$ \\
\hline \multirow[t]{5}{*}{ Piriápolis } & U. brasiliensis & 0.69 & 0.59 & U. brasiliensis & 0.66 & 0.77 \\
\hline & C. guatucupa & 0.16 & 0.27 & C. japonicus & 0.11 & 0 \\
\hline & C. japonicus & 0.11 & 0 & M. furnieri & 0.09 & 0 \\
\hline & Brevoortia sp. & 0.01 & 0.15 & C. guatucupa & 0.08 & 0.23 \\
\hline & & $\mathrm{W}=253.5 \mathrm{Kg}$ & $\mathrm{W}=19.6 \mathrm{Kg}$ & & $\mathrm{W}=214.9 \mathrm{Kg}$ & $\mathrm{W}=34.2 \mathrm{Kg}$ \\
\hline \multirow[t]{5}{*}{ La Paloma } & M. schmitti & 0.67 & 0.10 & U. brasiliensis & 0.39 & 0.24 \\
\hline & C. guatuсuра & 0.25 & 0.90 & C. guatucupa & 0.14 & 0.69 \\
\hline & U. brasiliensis & 0.06 & 0 & M. schmitti & 0.44 & 0 \\
\hline & & & & M. furnieri & 0.01 & 0 \\
\hline & & $\mathrm{W}=1114.6 \mathrm{Kg}$ & $\mathrm{W}=13.2 \mathrm{Kg}$ & & $\mathrm{W}=1177.1 \mathrm{Kg}$ & $\mathrm{W}=13.6 \mathrm{Kg}$ \\
\hline \multirow[t]{4}{*}{ Cabo Polonio } & M. schmitti & 0.89 & 0.74 & M. schmitti & 0.45 & 0 \\
\hline & C. guatucupa & 0.09 & 0.20 & U. brasiliensis & 0.39 & 0.19 \\
\hline & U. canosai & 0 & 0.06 & C. guatuсupa & 0.14 & 0.75 \\
\hline & & $\mathrm{W}=463.5 \mathrm{Kg}$ & $\mathrm{W}=11.0 \mathrm{Kg}$ & & $\mathrm{W}=225.3 \mathrm{Kg}$ & $\mathrm{W}=29.0 \mathrm{Kg}$ \\
\hline
\end{tabular}

$\mathrm{W}$ is the weight of the fish caught by the fishery or consumed by sea lions. Only proportions greater than 0.05 in at least one of the components are shown

\section{Trophic spectrum}

The Levin's index reflected that sea lions were specialists in all localities, except at Cabo Polonio, where they showed a more generalist diet (Levin's index= 3.53). Fisheries were specialist in catching a few (or one) species in all sites except at La Paloma with longlines (Levin's index= 3.0, Table 7). Comparing both types of fishing gear, fisheries tended to be more generalists when using longlines than with gillnets. In contrast, sea lions tended to show a more generalist behavior with gillnets, and were specialists with longlines.

Table 7. Results of the Levin's index for sea lions and fisheries at each locality, according to the fishing gear used.

\begin{tabular}{lccc}
\hline \hline FISHING PORT & Gear & B sl & B fshy \\
\hline \hline BUCEO & G & 2.13 & 1.65 \\
PIRIÁPOLIS & G & Max* $^{*}$ & --- \\
LA PALOMA & L & 1.86 & 2.06 \\
& G & 2.16 & 1.21 \\
CABO POLONIO & L & 1.26 & 3.00 \\
\hline \hline
\end{tabular}

* Only one fishing event with gillnets was monitored in Piriápolis, with no catch and all sea lion consumption concentrated in one species.

\section{Discussion}

South American sea lions showed mainly an opportunistic predatory behavior, with some cases of selection. Overall they may be defined as "plastic specialists" (Lowry et al., 1991) because despite being able to prey over a variety of species, few of them dominated in their diet.

Two general predatory strategies are apparent: one at the two fishing ports located on La Plata River estuary (Buceo and Piriápolis) and the other at the localities situated on the Atlantic Ocean coast (La Paloma and Cabo Polonio). In the first strategy, the most consumed prey were the same most caught by the fishery (Macrodon ancylodon and Urophycis brasiliensis), suggesting an opportunistic behavior as sea lions concentrated on the most important species for the fishery. Similarly, the trophic spectrum analysis suggested that in Buceo and Pirápolis sea lions and fisheries were specialists. In the second strategy, sea lions preyed mostly upon a species which was not the most important for the fishery, and exhibited local or seasonal selections. It seems also clear that some species were avoided, e.g. Mustelus schmitti at 
Cabo Polonio and at La Paloma, despite being important in the gillnet fishery. According to the trophic breath at La Paloma and Cabo Polonio, sea lions and fisheries did not coincide in the trophic spectrum.

These results only describe what occurs during the interaction with fisheries, and may not reflect the complete sea lion feeding spectrum. Nevertheless, dietary studies elsewhere have reached the same conclusions. According to Koen Alonso et al. (2000), South American sea lions in Argentina have a broadspectrum behavior, feeding upon species in the same proportion as their availability in the environment (such as the hake, Merluccius hubbsi). At Puerto Quequén (Argentina), Suárez et al. (2005) also define South American sea lions as opportunistic feeders, which consume a wide range of species and change seasonality according to prey availability in the environment. George-Nascimento et al. (1985) found that sea lions in central Chile tended to consume slow swimming bentho-demersal fish (such as hake, Macruronus magellanicus, which was the most important in mass in the diet), rather than the more abundant pelagic fish (such as jack mackerel, Trachurus murphyi). The niche breadth analysis developed by Hückstädt and Antezana (2006) in north and south-central Chile is very similar to my results. South American sea lions were defined as generalists overall, but showed a specialist diet at almost every location, reflecting plastic trophic habits according to the abundance of local and seasonal prey (i.e. opportunistic).

In Uruguay, Naya et al. (2000), based on otolith identification from scats, concluded that South American sea lions were generalists, with C. guatucupa, Anchoa marinii and Trichurus lepturus being the dominant species in the diet. Of these three species only $C$. guatucupa was caught by artisanal fisheries. This species in particular was the most preyed upon at La Paloma and Cabo Polonio, and preferentially selected at the former location. C. guatucupa was also one of the most important prey for sea lions and a target species for coastal fisheries in a non-breeding rookery at Puerto Quequén, Argentina, where the fish community is similar to that in Uruguay (Suárez et al,. 2005). This species may be a source of conflict between sea lions and artisanal fisheries in that area.

Opportunism may imply a certain degree of conflict with the artisanal fishing activity. Whether sea lions freely select prey underwater or take advantage of escaping fish from fishing gear cannot be determined with these data. Nevertheless, it seems likely that they may take fish from the gear, as suggested by opened hooks and many tears often found in gillnets.

This particular behavior is probably a specialized foraging strategy exhibited only by some animals within the population. Most of the interacting sea lions in this area were females or subadult males (Szteren and Páez, 2002). Lactating females remain in coastal areas close to the rookeries and may overlap with fishing grounds (Campagna et al., 2001). Sex segregation in feeding areas has been reported for other sea lion species, and would be associated with the lactating activity of females that need to return frequently to the rookeries in order to feed their pups (Merrick et al., 1997; Boyd et al., 1998; Bonadonna et al., 2001; Bailleul et al., 2005). Males, on the other hand, disperse over longer distances to optimize foraging intake, for which they are physiologically capable (Hernández-Camacho, 2001), and cope with the energetic constraints during reproduction (Campagna et al., 2001).

Seasonal differences in selectivity are not surprising, as sea lions may switch to an alternative prey when the seasonal abundance of their main target declined (e.g. Ainley et al., 1982; Sinclair et al., 1994), reflecting fluctuations in prey distribution and abundance (Hume et al., 2004), or related to sea lion reproductive status (Kastelein et al., 1995). In South American sea lions, both prey availability and selectivity can change seasonally as was found by Suárez et al. (2005) in Argentina and George-Nascimento et al. (1985) in central Chile. This may be related to the nutritional needs of sea lions in different seasons of the year. Fish of a certain species can have different nutritional or caloric values depending on the season and geographical area (Kastelein et al., 1995). Thus, prey switching might be an important aspect of sea lion feeding behavior. As part of their reproductive cycle, adult South American sea lions fast part of the summer (breeding season) and forage more actively during autumn and winter. Consequently, changes in prey composition or diversity are expected. Unfortunately, no data on seasonal dietary changes for Otaria flavescens in Uruguay are available for comparisons.

The methods used to study pinniped prey selectivity have been based on the identification of hard remains from scats or stomach samples, and compared with fishery landings (usually trawls) (e.g. George-Nacimento et al., 1985; Sinclair et al., 1994; Tollit et al., 1997; Koen Alonso et al., 2000; Zeppelin et al., 2003). There are biases associated with most of these methods. First, the identification of hard part remains depends on the proper identification of otoliths, which requires a comprehensive reference collection, and there are issues related to differential otolith degradation, selective longer retention times of remains, and discards of the head of large fish (Dellinger and Trillmich, 1988; Naya et al., 2002). Second, samples collected from fisheries do not usually coincide in time with sea lion prey collections, and there is no certainty if the collected prey samples belong to animals being observed interacting with the fisheries. Third, fishery databases have many limitations, as they are usually inexact in the species reported and amounts landed, and areas of fishing sometimes do not coincide with the area of data reports. In this study, the mentioned biases were minimized by directly observing sea lion consumption, simultaneously with fishery catches recorded fish by fish for the sampled vessels. 
Some fish may have been missed or erroneously identified due to the distance of the sea lion from the boat or its position, which made it difficult to observe correctly. This lack of information may introduce serial bias in the index values. However, this problem is constant throughout all the sampling ports, times of the year and fishing gear, so it can be assumed that this estimation should not differ significantly from what was sampled and allow for the comparisons.

Some bias also occurred as a consequence of fish consumed underwater, which was not observed. It should be noted that the sample of possible prey species did not include all the fish in the environment, but only those caught by the artisanal fishing gear. So, fish too small (such as Anchoa marinii) or not caught by this fishing gear (such as Trachiurus lepturus) previously mentioned as prey species (Naya et al., 2000) were not included in this selectivity analysis. I assume that these were small fish so they are beyond the objectives of this comparison because they are not targeted or caught by these fishing gear.

It has been mentioned that passive fishing gear is more vulnerable to predation by pinnipeds than active gear such as trawling nets (Wickens, 1995; Harwood, 1987). Trawling gear likely would catch a greater variety of species (i.e. being less selective and more generalist), so less interaction with sea lions and greater selectivity can be expected.

These preliminary results suggest that sea lions in Uruguay have an opportunistic feeding behavior, occasionally preying selectively on some species targeted by the fishery in selected areas or seasons. Thus, sea lion predation over artisanal fisheries catches may not be as important as it is currently believed, as suggested by studies quantifying damages to fishing gear (Szteren and Páez, 2002). It is likely that the broad dietary spectrum and opportunistic behavior of sea lions allow them to buffer the effects of a high degree of overlap with fisheries (Campagna et al., 2001).

\section{Acknowledgements}

I wish to thank Daniel Naya and Matías Arim for assisting with calculations and discussions on a previous version. Fernando Elorriaga helped with discussions as well. I also acknowledge the valuable contributions of Enrique Crespo, Nélio Barros and an anonymous referee to improve the article. Programa de Maestría en Manejo de Vida Silvestre- Universidad Nacional de Córdoba, Argentina, provided funds for data collection. I am very grateful to all fishermen who allowed me to make observations onboard their boats.

\section{References}

Ainley, DG, Huber, H.R. And Bailey, K.M. (1982) Population fluctuations of California sea lions and the Pacific whiting fishery off central California. Fishery Bulletin 80(2): 253-258.
Agresti, A. (1984) Analysis of ordinal categorical data. John Wiley \& Sons, New York, NY. USA. 287 pp.

Bailleul, F., Luque, S. Dubroca, L. Arnould, J.P.Y. AND Guinet, C. (2005) Differences in foraging strategy and maternal behaviour between two sympatric fur seal species at the Crozet Islands. Marine Ecology Progress Series 293: 273-282.

BEVERTON, R.J.H. (1985) Analysis of marine mammal-fisheries interactions. Pages 3-33 in Beddington, J.R., BEverton, R.J.H. and Lavigne, D.M. (Eds) Marine Mammals and Fisheries. George Allen \& Unwin, London, United Kingdom.

BONNER, W.N. (1982) Seals and man. A study of interactions. Washington Sea Grant Publication, University of Washington Press, Seattle and Washington. 170p.

Bonadonna, F., Lea, M-A., Dehorter, O., Guinet, C. (2001) Foraging ground fidelity and route-choice tactics of a marine predator: the Antarctic fur seal (Arctocephalus gazella). Marine Ecology Progress Series 223: 287-297.

BOYD, I.L., MAcCAFFERTY, D.J., ReIs, K., TAYLOR, R. AND WALKeR, T.R. (1998) Dispersal of male and female Antarctic fur seals (Arctocephalus gazella). Canadian Journal of Fisheries and Aquatic Sciences 55: 845-852.

Campagna, C., Werner, R., Karesh, W., Marin, M.R., Koontz, F., CooK R. AND Koontz, C. (2001) Movements and location at sea of South American sea lions (Otaria flavescens). Journal of Zoology, London 257: 205-220.

David, J. AND Wickens, P. (2003) Management of Cape fur seal and fisheries in South Africa. Pages 116-135 in GALES, N. HiNDELL, M AND KIRKWOOD, R. (Eds) Marine Mammals. Fisheries, Tourism and Management issues, CSIRO Publishing, Collingwood, Australia.

Dellinger, T. And Trillmich, F. (1988) Estimating diet composition from scat analysis in otariid seals (Otariidae): is it reliable? Canadian Journal of Zoology 66: 1865-1870.

George-Nascimento, M., Bustamante, R. AND Oyarzun, C. (1985) Feeding ecology of the South American sea lion Otaria flavescens: food contents and food electivity. Marine Ecology Progress Series 21: 135-143.

Harwood, J. (1987) Competition between seals and fisheries. Scientific Progress, Oxford 71: 429-437

HernándeZ-CAmacho C.J. (2001) Tabla de vida del lobo marino de California Zalophus californianus californianus en la lobera Los Islotes, B.C.S., México. MSc. Thesis. Instituto Politécnico Nacional, CICIMAR. La Paz, B.C.S. México. 67 pp.

HÜCKSTÄDT, L.A. AND ANTEZANA, T. (2006) The diet of Otaria flavescens in Chile: what do we know? Pages 83-102 in Trites, A.W., AtKInson, S.K., DeMaster, D.P., Fritz, L.W., Gelatt, T.S., ReA, L.D. AND Wynne, K.M. (Eds) Sea Lions of the World. Alaska Sea Grant College Program, University of Alaska Fairbanks, Fairbanks, USA.

Hume, F., Hindell, M.A., Pemberton, D. and Gales, R. (2004) Spatial and temporal variation in the diet of a high trophic level predator, the Australian fur seal (Arctocephalus pusillus doriferus). Marine Biology 144: 407-415.

KajIMURA, H. (1984) Opportunistic feeding of the northern fur seal, Callorhinus ursinus, in the eastern North Pacific Ocean and eastern Bering Sea. NOAA Technical Report NMFS SSRF-779.

Kastelein, R.A., Kershaw, J., Berghout, E. and WiepKema, P.R. (1995) The food consumption of South American sea lions (Otaria flavescens). Aquatic Mammals 21(1): 43-53. 
Krebs, C.J. (1999) Ecological Methodology. Addison Welsey Longman. Menlo Park, CA, USA. 620 pp.

Koen Alonso, M., Crespo, E.A., Pedraza, S.N., García, N.A and Coscarella, M.A. (2000) Food habits of the South American sea lion, Otaria flavescens, off Patagonia, Argentina. Fishery Bulletin 98(2): 250-263.

Lowry, M.S., Stewart, B.S., Heath, C.B. Yochem, P. K. and FRANCIS, J.M. (1991) Seasonal and annual variability in the diet of California sea lions Zalophus californianus at San Nicolas Island, California. 1981-86. Fishery Bulletin 89:331-336.

Marsh, H., Arnold, P., Freeman, M. Haynes, D., Laist, D., Read, A., REYNOLDS, J. AND KASUYA, T. (2003) Strategies for conserving marine mammals. Pages 1-19 in Gales, N., Hindell, M., and Kikwood, R. (Eds). Marine Mammals. Fisheries, Tourism and Management issues. CSIRO Publishing, Collingwood, Australia.

Merrick, R.L., Loughlin, T.R. AND CaLKINS, D.G. (1987) Decline of the northern sea lion, Eumetopias jubatus, in Alaska, 195686. Fishery Bulletin 85(2): 351-365

Merrick, R.L., Chumbley, M.K. and Byrd, G.V. (1997) Diet diversity of Steller sea lions (Eumetopias jubatus) and their population decline in Alaska: a potential relationship. Canadian Journal Fishery Aquatic Sciences 54: 1342-1348.

Moore, P.J. (2003) Seals and fisheries in the Clyde Sea area (Scotland): traditional knowledge informs science. Fisheries Research 63: 51-61.

Naya, D.E., Vargas, R. ANd Arim, M. (2000) Análisis preliminar de la dieta del león marino del sur (Otaria flavescens) en Isla de Lobos, Uruguay. Boletín de la Sociedad Zoológica Uruguay, 12: 14-21.

NaYA, D.E., ARIM, M. AND VARGas, M. (2002) Diet of South American fur seals (Arctocephalus australis) at Isla de Lobos, Uruguay. Marine Mammal Science 18(3): 734-745.

Schoener, T.W. (1972) Theory of feeding strategies. Annual Review of Ecology and Systematics 2: 369-404.
Sinclair, E., Loughlin, T. And Pearcy, E. (1994) Prey selection by northern fur seals (Callorhinus ursinus) in the eastern Bering Sea. Fishery Bulletin 92: 144-156.

Suárez, A.A., Sanfelice, D., Cassini, M.H. and Cappozzo, H.L. (2005). Composition and seasonal variation in the diet of the south american sea lion (Otaria flavescens) from Quequén, Argentina. Latin American Journal of Aquatic Mammals 4(2): 163-174.

Szteren, D. (1999) Impacto económico del león marinos sudamericano (Otaria flavescens) sobre la pesca artesanal en Uruguay. MSc. Thesis. Universidad Nacional de Córdoba, Argentina. 59 pp.

Szteren D. And PÁez, E. (2002) Predation by southern sea lions (Otaria flavescens) on artisanal fishing catches in Uruguay. Marine and Freshwater Research 53(3): 1161-1167.

Tollit, D.J., Greenstreet, S.P.R. And Thompson, P.M. (1997) Prey selection by harbour seals, Phoca vitulina, in relation to variations in prey abundance. Canadian Journal of Zoology 75: 1508-1518.

VAz Ferreira, R. (1975) Behavior of the southern sea lion, Otaria flavescens (Shaw) in the Uruguayan islands. Rapports et Procés Verbaux, Conseil Internacional pour L'Exploration de la Mer 169: 219-227.

Werner, R. and Campagna, C. (1995) Diving behaviour of lactating southern sea lions (Otaria flavescens) in Patagonia. Canadian Journal of Zoology 73: 1975-1982.

Wickens, P.A. (1995) A review of operational interactions between pinnipeds and fisheries. FAO Fisheries Technical Paper 346: 86 pp.

Zeprelin, T.K., Tollit, D.J., CAll, K.A., Orchard, T.J. and Gudmundson, C.J. (2004) Sizes of walleye pollock (Theragra chalcogramma) and Atka mackerel (Pleurogrammus monopterygius) consumed by the western stock of Steller sea lions (Eumetopias jubatus) in Alaska from 1998 to 2000. Fishery Bulletin 102: 509-521. 